\title{
Contemporaneity of Spanish Rural Architecture Intervention and Economic Sustainability
}

\author{
Joan Curós Vilà1, M. Pilar Curós Vilà ${ }^{2}$ \\ ${ }^{1}$ Architectural Design Department, Architecture School of the Vallés (ETSAV), Universitat Politècnica de Catalunya, \\ Barcelona, Spain \\ ${ }^{2}$ Department of Accounting, Faculty of Economics and Business, University of Barcelona, Barcelona, Spain \\ Email: joan.curos@upc.edu, pilar.curos@ub.edu
}

How to cite this paper: Curós Vilà, J., \& Curós Vilà, M. P. (2017). Contemporaneity of Spanish Rural Architecture Intervention and Economic Sustainability. Art and Design Review, 5, 52-72.

https://doi.org/10.4236/adr.2017.51005

Received: November 4, 2016

Accepted: February 13, 2017

Published: February 16, 2017

Copyright $\odot 2017$ by authors and Scientific Research Publishing Inc. This work is licensed under the Creative Commons Attribution International License (CC BY 4.0).

http://creativecommons.org/licenses/by/4.0/

\begin{abstract}
From the second half of the $20^{\text {th }}$ century onwards, Spanish rural architecture has suffered a transformation regarding its farming and ranching model. The economic unsustainability of the family economy has led to further action for the viability of the system. This transformation has meant a new mindset to the owner of the farm and livestock, who had to consider whether continuity was given to the exploitation or the countryside/field was changed and adapted to a new use such as rural tourism, restoration, or for collective uses such as holiday camps, cultural centers or others. Owners who have decided to continue the exploitation they were developing have had to industrialize it and thus extend it in a considerable percentage. That has meant the need to intervene significantly in the rural architectural heritage. A wide and varied range of results has been obtained in these interventions: from the fossilization or destruction of assets, to the achievement of harmony and coexistence between tradition and modernity in this heritage, the result of which represents the contemporaneity of rural architecture.
\end{abstract}

\section{Keywords}

Rural Architecture, Economic Sustainability, Architectural Intervention,

Relationship between Economy and Rural Architecture,

Rural Contemporary Architecture

\section{Introduction}

One of the most powerful elements of the rural landscape is housing (Woods, 2005) which is surrounded by the fields that are part of the same agricultural and livestock activity which constituted an economic and legal unit (Garcia, 1975) that remains today as an indivisible farm. 
In Spain rural homes have a wide toponymy that identifies them according to the Autonomous Community where they are located. For instance, going from north to south of Spain, we have Galicia with its Pazo and the Hórreo as a secondary building; in the País Vasco there is the Caserío, the Masia in Catalonia, in Valencia the Barraca, in Mallorca the Possessió and in Andalucía the Cortijo.

For centuries the Spanish rural economy has rested in a substantial way in subsistence agriculture. As operating units were generally small, farmers were not allowed to maintain a number of heads that could enable them to make a living from livestock only. Therefore this activity was combined with subsistence farming (García, 1975). The capacity of the plants was also reduced, which didn't allow a large number of cattle. It was a simple manifestation of a rural economy of autarkic character.

Fonseca considers that "the fundamental problem is that the house should be considered as an instrument of rural exploitation, whose repayment must tax the remaining agricultural costs".

At the late nineteenth century and early in the twentieth century the existence of that concern is observed at least since modern programs of economic reform and rural society are formulated. Reform implies the need to adapt the conditions of the area to the new demands of agrarian capitalism (Monclús \& Oyon, 1988).

From the second half of the twentieth century small farms gradually became economically unviable by its need for modernization and therefore of considerable economic investment.

This meant that those who decided to continue the exploitation of the work had to transform the construction of new buildings and adapt the existing humble buildings, in order to obtain adequate facilities according to the change in the economic model of agricultural and livestock exploitation (Giménez \& Sanchez, 1994).

This has also meant a significant transformation for the rural architectural heritage due to the industrialization of the same holding or to the acquisition of a new use intended to rural tourism, catering, social practices or other.

In those devoted to new uses, the original distribution has been in many situations completely modified in order to suit the housing needs of the new use. In other situations, due to the lack of financial means, junior fittings have been made, such as painting, repairing cracks, removing dampness, etc. (Curós, 2004). Building a bathroom and a kitchen has been the prototype for expansion or renovation exceeding the initial lack of toilets. When the family has continued to live in the same house and has expanded, its operation has been significantly reforming housing services (Villanueva \& Leal, 1991).

Of all the interventions, no matter whether they are alterations, additions or new constructions in such a distinctive architecture and a very sensitive and vulnerable landscape, in a too high percentage results are not very satisfactory. In many situations there has been little enough respect and sensuality in translating the rural architectural language in contemporary times. The current legis- 
lation is collaborating in obtaining these results due to its rigidity and to unilaterally lead the designer to obtain clones of this architecture (Curós, 2004).

In the farm, like in other jobs, the available family labour and the non-strictly monetary exchanges, as well as the ability of management and decision of the household, are vital elements not only for the holding to move on, but also for the failure of the economic development of others (Giménez \& Sanchez, 1994).

Commercial agriculture experienced a significant improvement from the year 1940. The two main agricultural products were cereals and wine products. The evolution of Spanish livestock had similar trends although being less dramatic (Monclús \& Oyon, 1988).

The rural world has recently come into an accelerated phase of transformation and has fully entered into the market circuits, losing more than half of its manpower and altering its cultural habits and landscape.

The progressive development of capitalism has simultaneously led to an impoverishment of small agricultural entrepreneur (Etxezarreta, 1977).

This situation has happened not only in Spain but throughout Europe, where the traditional agriculture of artisanal and family type has been disappearing and has been replaced by a more industrial agriculture with entrepreneurial features.

In Spanish agriculture, the abandonment of the field by small farmers has taken place parallel to the establishment of large farms and livestock enterprise mounted by former landlords or absentee new capitalists with exploitations based on paid labour.

The progress of agriculture and its productive orientation is increasingly subordinated to the monopolistic strategy of the strongest sectors of the industrial monopolies (Etxezarreta, 1979).

It has been observed in Spain a break of the correlation between agriculture and the rural economy (Garrabou, 2010).

The policies are designed to support models of industrial and corporate agriculture, concentration of food distribution in the hands of 4 or 5 large areas, and the entry of subsidized food that compete unfairly with local products (Duch, 2010).

We can say that in the family farm a family exploits land "by exploiting itself" (Naredo, 1996).

\section{Methodology}

The methodology of this research has had its difficulties simply because there are no records in the different Spanish Autonomous Communities. These include however the whole number of existing rural households which are still active, having transformed farming and ranching to adapt them to our days, or having acquired a new use. There is no kind of homogenization among the records that exist between regions or they are not classified by the different uses. Therefore the study responds to a reading and interpretation of the data available by regional governments as it would be impractical to have to do this fieldwork in the whole of Spain; yet this study leads to a diagnosis of the current situation of this 
interesting and rooted vernacular heritage. This information could be obtained through public administration, by means of licensing for architectonic interventions or for use changes. Thus, it would be necessary to unify a record with the same data and criteria, which should be available in each region. This would enable the achievement of dated, much more homogenized studies for the whole country, which would allow being aware of the health of this rural heritage.

\subsection{Study Areas}

This study was conducted in six regions of Spain which show a representativity of the whole country comprehensively. These communities differentiate themselves by having a very distinctive and unique rural architecture of the place and with great personality which shows a range of diverse and interesting rural architecture in the country.

The six types of rural architecture offer a complete reading of Spain, by responding to the geographic and climatological diversity of each of the most significant rural areas of the Spanish territory: from the north (mountainous) to the south (plains) and the Mediterranean coast and Balearic Islands (in the Mediterranean sea).

The studied communities and the nomenclature of its rural architecture is as follows:

1-Galicia: Pazo (housing) and Horreo (building for agricultural use)

2-País Vasco: Caserío

3-Cataluña: Masía

4-Valencia: Barraca

5-Malllorca: Possessió

6-Andalucia: Cortijo

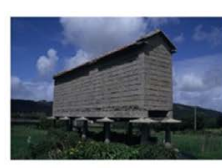

Hórreo

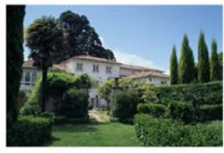

Pazo

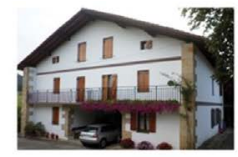

Caserío

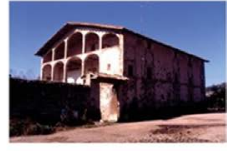

Masia

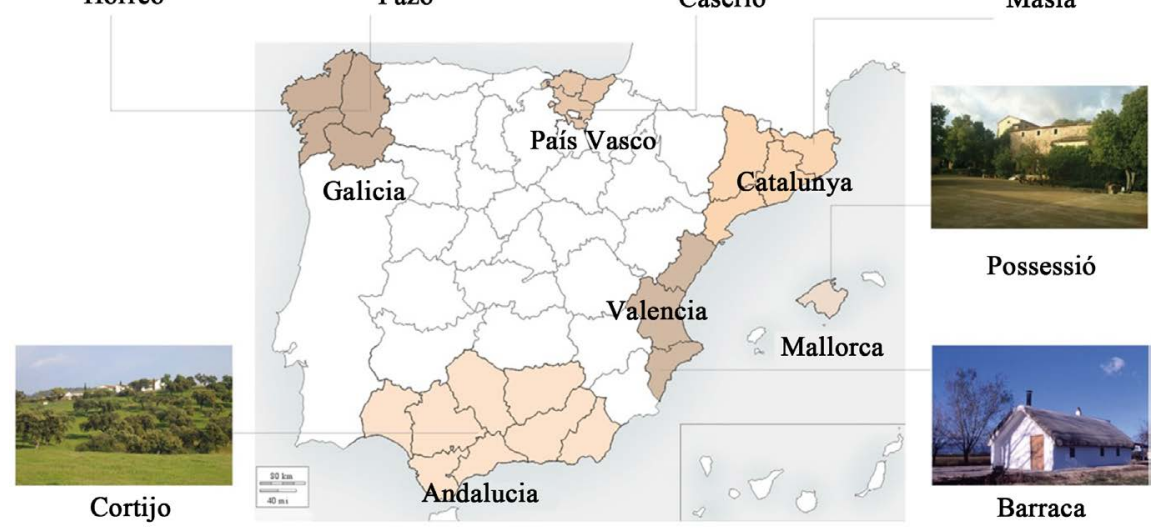

The Pazo and the Hórreo

The Pazo is a Galician rural house of manor type. Its name derives from pa- 
lace and is described as a stately mansion. It is related to the monastic architecture and constitutes a solid walled building containing the manor itself and annexed buildings within the same enclosure with garden. They usually contain one or two towers originally with a defensive purpose. They have three floors, ground floor and first floor, which is for housing, and the attic. The interior layout of the manor of the main floor has several bedrooms, some of which are interconnected, the living room and dining room, and a reception room for visits preceded by a hall and kitchen.

The facades are thick walls of local stone with a wood structure and Arab-tile roof.

The outbuildings used to house the family of stewards, who took care of the noble family, the surrounding land and the animals housed in their blocks.

In the enclosure there was usually a dovecote and a chapel.

Another building very common in rural Galicia, the "hórreo", is a very particular construction because of its structure, and is designed to store and dry agricultural products, as a barn.

It is a key element in the architectural, economic and cultural context of the Galician countryside. Its most common use is for the storage, drying and retaining of corn because it is necessary to have good ventilation, insulation and moisture protection as well as a proper system of defence against insects, rodents and birds. Mainly they are rectangular but there are circular or square ones as well.

It is constructed with stone, wood or mixed-construction and they are raised off the ground with a small structure of stone or wood supports, feature which prevents soil moisture and provides ventilation. The pitched roof can be of various types: thatch, slate, stone tiles or Moorish tiles.

The sides of the barn have slots or gaps to dry and ventilate the grain stored therein (Pérez, 2010).

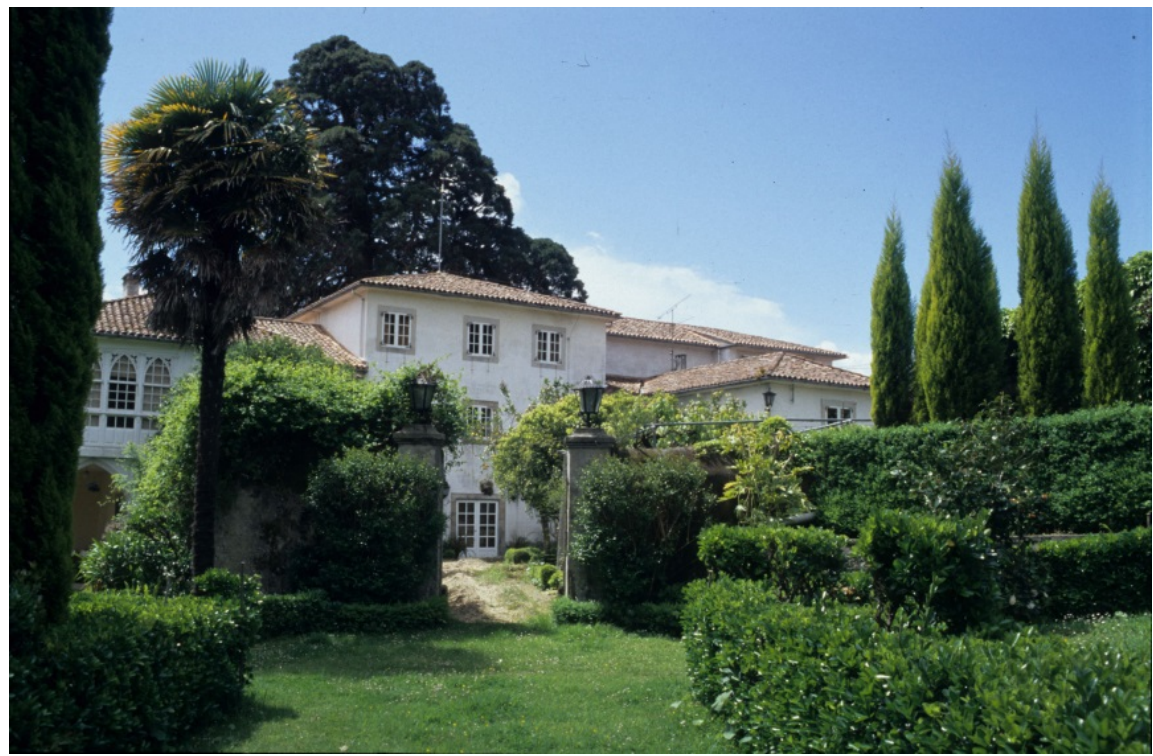

Pazo Santa Marta de Bavio. A Coruña. Photograph: Joan Curós 


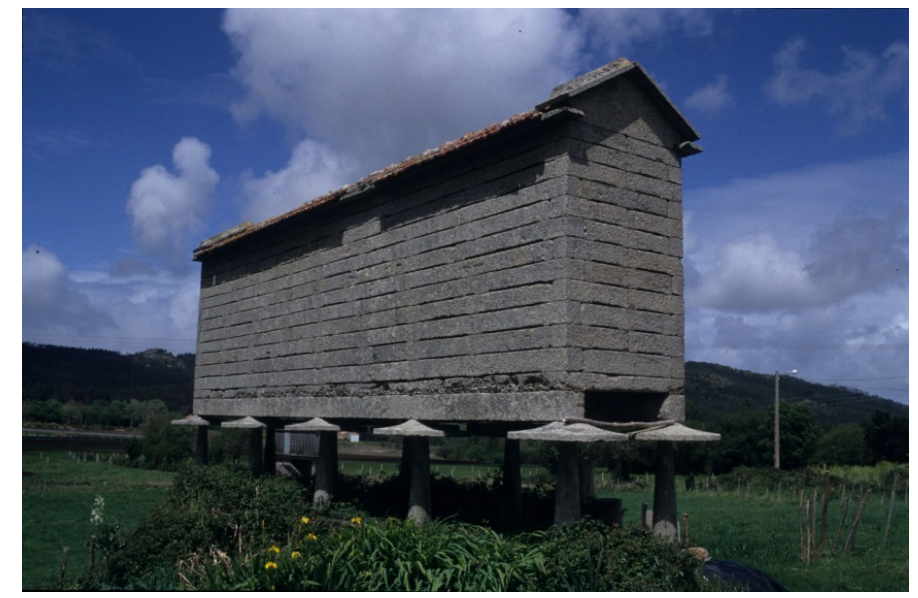

Hórreo A. Sayo. A Coruña. Photograph: Joan Curós

\section{The Caserío}

The Caserío is an isolated rural home surrounded by its land and other buildings in the rural exploitation of the Basque Country with both morphometric and constructive features according to the site.

They are based on the ground floor, mostly devoted to animals, crops and forages and the top or upper floors where the home and the barn were located.

As for the constructions, they are made of stone and wood panelling, with pitched roof on stand perpendicular to the main facade covered with Arabic tiles (Ainz, 2001).

There are villages built largely of wood mainly up to the sixteenth century. Thereafter stone dominates depending on the region and the abundance of a particular building material. In combination with the wood, brick is used creating a type of house that bears a striking resemblance to the farmhouses of some regions of Switzerland and southern Germany. Horizontal brick or masonry filling can be perceived, as well as the structural framework drawing. Both features give the village a great visual beauty.

This new system allowed new schemes, such as changing the layout of the facades and interior organization. In the twentieth century the cubic "caserío" dominates, with four slopes. In the eighteenth century the Tower houses reach their best expression. They are the well-known palace "caserios" with volume and stone as main characters.

Nevertheless, the ground floor used to be generally raised with masonry factory, as well as the facade exposed to rain.

Very typical to the Basque Country are the very flown eaves, supported by other props.

The organization of the floors of the "caserío" has a great simplicity. Almost all "caseríos" are oriented towards the East or the South The floor is divided into three bays to the main facade. When there is a dwelling in the ground floor, the sides are usually occupied by kitchen and bedrooms, and the center one is intended to a passage that leads to the block. Almost all floors of this type allow the house to have two dwellings. On the floor, accessible by a staircase, there are 
the remaining bedrooms to the side and very often a room with alcove, where the great feasts are held and the guests are housed in the central bay.

The complete absence of toilets in most "caseríos" is striking, and it is not conceived ordering the laundering of villages inside and outside, and this state of things is tolerated at odds with all the precepts of hygiene (Baeschlin, 1968).

The main entrance is located usually on the main facade facing south and in some cases through the porch, prior to the entry porch, although there are "caseríos" where it can be found in a side facade.

The farmhouse is a basic unit of economic production and social reproduction.

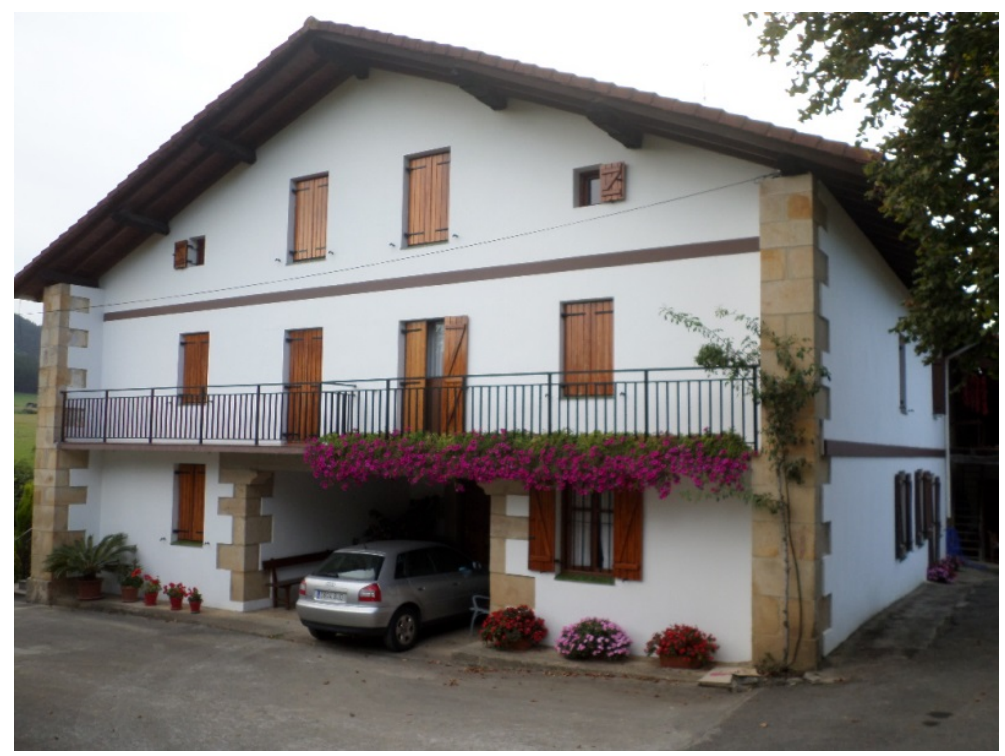

Caserío Aurtenetxe-Mungia. Vizcaya. Photograph: Joan Curós

\section{The Masia}

The "Masia" is the most significant icon of the rural world from Catalonia. It is the isolated dwelling in rural area where it shelters those people whose task is to take care of the farming and ranching as family economic structure. It is articulated with other secondary buildings intended to house livestock and crops derived from the land. The ensemble of these elements, buildings and land is known as "mas".

The first Masia appeared between the ninth and tenth centuries although most date from the fourteenth and fifteenth centuries. In the eighteenth century there was a boom of growth and reforms in most of them due to agricultural splendour, a feature which was projected on buildings and especially in the farmhouse (Curós, 2004).

The Masia was not a closed building but grew throughout its history answering the needs of the same property, both at the agricultural and the livestock level.

Its exterior morphology varies depending on the geographical area where it is located and therefore there are different types of them. Regarding its organiza- 
tion and internal structure, there is a fairly widespread prototype of the three bays with walls perpendicular to the main facade facing generally south (Curós, 2004).

There are two bays farmhouses and others with more than three bays, which are added through their respective growths from the body of classical structure or three-bays-structure named as the architect Josep Danés, a scholar expert in the subject of the masia.

Almost all of them have ground floor, main floor and attic floor. In the humblest situations, the ground floor was shared between animals and people. The kitchen, the cellar and other outbuildings were on the first floor. In many other farm houses, the living place was entirely in the first or main floor, with a wider central bay room known as the noblest area of the house used for family celebrations, and the side bays intended for the bedrooms. It was common to place the kitchen at the end of the central and north-sided corridor. Upstairs, there was the area to store grain or crops as space ventilation and drying of grain products, which acted simultaneously as insulation to avoid heat dissipation (Curós, 2006).

The construction processes were simultaneously simple and effective, which offered an architecture without any pretension but with great functionality. The materials used were in its vicinity, stone and wood due to the reduced ability of means of transport at that time. Therefore the result was an architecture in a dialogue with the place, based on thick perimeter walls of stone and mortar with wooden structure (Curós, 1995, 1999).

It was common in the manorial masies to have in its facades or at least in the main ones a white painted plastering to protect the wall. It was also common to have arched galleries that gave a more important architectural aspect to the farm and used to match frontally with the access road. Most of them had been added during the eighteenth century to give more impetus on its facade which functionality was to prolong the interior rooms that led to them.

The main entrance of the house is often the one which is on the south side, which is also the most relevant one of the house (Curós, 2004).

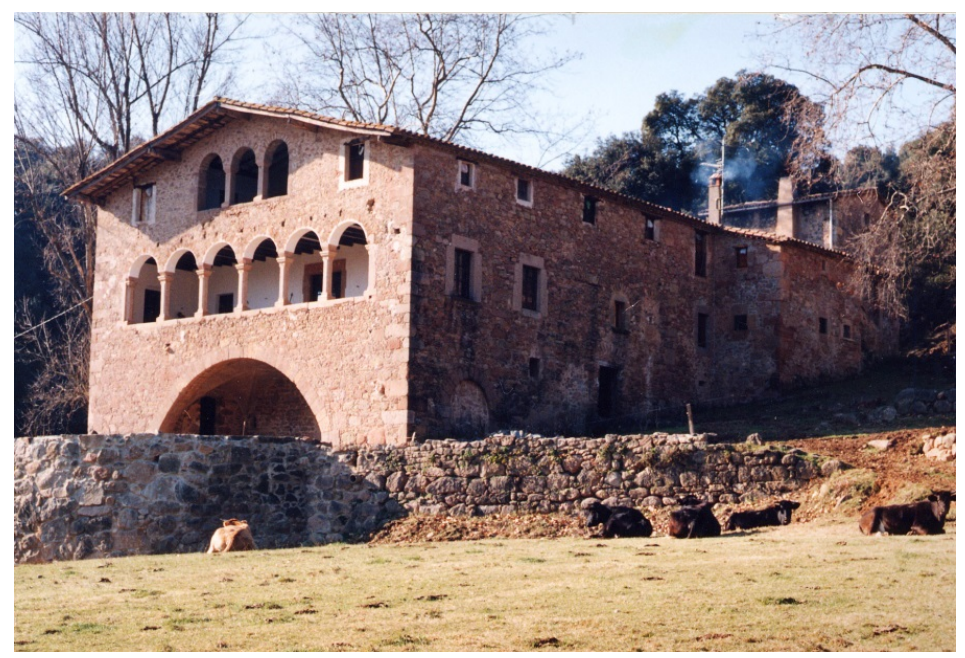

Masia el Callís. Vall de Bianya. Gerona. Photograph: Joan Curós 


\section{The Barraca}

The barraca is parallelepiped-plant construction next to the $1 / 2$ proportion between the walls front and side, built with side walls of adobe and wood piedroits on which a high-inclination vegetal cover stands. It forms a very obliquedihedral angle with the ridge cap, which closes the upstream and downstream facades with non-load-bearing elements (Sanchís, 1999). It is a typical construction transformed after a strong process of idealization, the symbol of the house of the Huerta of Valencia.

The original forms of the shed floor were elliptical or slightly rounded up to become rectangular, which stabilizes the shape of the barraca. From this geometric configuration, the interior space maintains a full process of transformation that presents a few alternatives changing throughout history. The Barraca contains a side corridor that opens the doors to the upstream and downstream façade through which the various units that occupy the opposite side are connected (del Rey, 2010).

According to Max Thede, originally there was only one interior centralized space and centralized with a home. This interior space was later compartmentalized and the doors on the sides close to the plant were kept. Over time the main stay, which contained the home, is placed at the entrance, and the home is settled attached to one side of the plant.

Three constructive elements define the barraca: the right feet, the walls of enclosure, and the cover.

The most primitive walls include right feet of wood, called winds, which support the covering structure; the space was closed with hurdles covered with mud. Later walls are continuous and build with dried adobe and straw. A ridge beam rests on these walls and supports the structure of the covering. These walls have usually a considerable thickness, approximately $45 \mathrm{~cm}$. They are placed by clay as mortar and the unions are revised with clay or mud. The perimetral wall is crowned with a chariot crossbeam that serves as support to the sloping and horizontal suspenders of the covering and the roof structure (del Rey, 2010).

The structure of the roof is formed by a beam ("biga solera") plus the aerial structure, which is made of some parts called "pares de lima" or tilted structure that constitutes the dihedral of cover. In addition there is also the beam ("bigacumbrera") that unifies the whole, and the straps of assembly. The hurdle of the roof is made with canes tied to a rope and coated with gypsum mortar by both sides. It is covered with vegetation placed in sheaves with a thickness of $15 \mathrm{~cm}$ thick overlapping approximately $1.10 \mathrm{~m}$ with layers tied to the support of the perpendicular cane and ends with a layer of mud on the ridge. Subsequently the points are trimmed, are bundled and the sheaves are combed with forks of cane (Curós, 2004).

The front and back enclosure will be carried out with a partition of double reed subject to tilted straps and horizontal beam with perpendicular canes placed in its interior that is mixed with clay mud and with litter of approximately 12 cm (Gosálvez, 1998). 


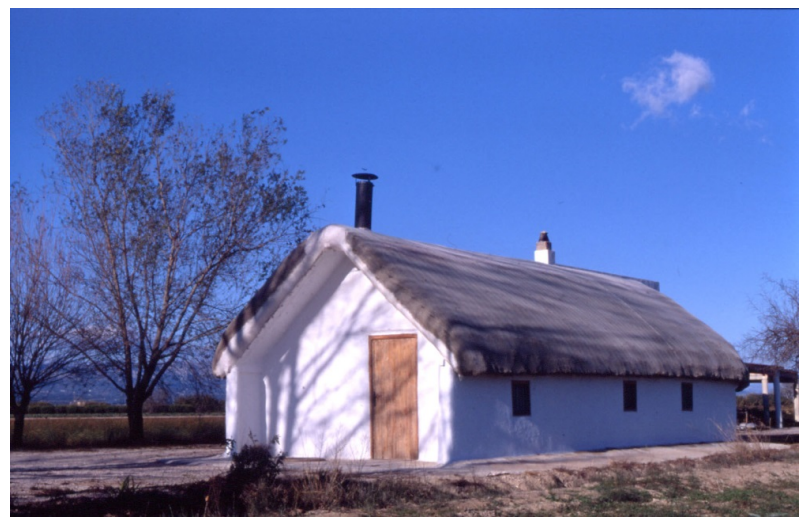

Barraca of Valencia. Photogrph: Joan Curós

\section{The "possessió"}

The possessio is an emblematic witness of the architecture and countryside of Mallorca (Valero, 2014).

The possessió concept, referring to large parcels of land for the cultivation and field work and organized around an architectural complex, is well known in the Majorcan culture since medieval times for its important relationship with, among others, territorial, economic and social aspects.

The fundamental characteristic of their origins were fortified structures because the first necessity of the new settlers was protection (Hernandez, 2014).

Many of them are far from the coast in order to prevent attacks and looting of piracy. They are often placed on a small hill or elevation, or on the slopes of the mountain, locations that were exploited to collect rain water coming from the top of the mountain. They would also be established at the boundary between the land suitable for cultivation and the forest environment (Garcia \& Oliver, 1986). Some exceptions are on the coast though.

The possessió is an ensemble composed of the cases delssenyors (houses of the landlords), cases delsamos (houses of the tenants), rooms for the missatgers (messengers) and other laborers, gardens, mills, warehouses, barns, stables, pigsties and other agricultural outbuildings.

Throughout history they have been growing according to the needs of the farm. A common structure in possessions allows the enlargement of the building forming a central closed courtyard of the house known as clastra as a protection element.

In most cases, they are simple structures, of rectangular plant with one or two bays and variable height, between one and three floors. In its development, galleries and porches have been added throughout the nineteenth and early twentieth century.

The access to the estate is often perpendicular to the main facade and to the access of the dwelling. The well-known portal fora is the access to the courtyard, formed by a round arch or segmental arch with stone voussoirs which acquires an excellent role in the courtyard.

The courtyard is a distributor space, from which different parts of the architectural ensemble are organized. It eases also the access to the casa dels senyors, 
the casa dels amos, the chapel or agricultural units, such as wine cellar to keep the mill to the production of oil or the barn or barns for storing grain and straw crops. The pavement of the courtyard is usually made of boulders, which are sometimes combined with slabs (Vibot, 2007).

The finish of the facades is in many of them a light color plaster, although there are also other ones with an exposed stone finish.

The social hierarchy in possesio is a characteristic feature of this type of assembly. It is common to have a main body, wider than the rest with a maximum of three floors. Downstairs, we can find the tenant's house (casa de l'amo), where the kitchen and the dining room would be located, along with other places dedicated to provide shelter to workers. There is also a noble floor, where the landlord would reside during his stay in the possessió. In the case there was a third floor, it was normally used as storage place or as residence for workers. Furthermore, it is common to allocate to the noble floor the second floor of the body that closes the entrance floor, leaving, on the first floor, space for a porch or lobby.

The chapel is a present element in many of the possessions. Its provision varies within the architectural ensembles but tends to be in one of the sides of the lobby of the possessió between the portal forà and the courtyard. In other situations it is located in the inner courtyard. It is a simple type of small rectangular plant covered with star-shaped vault.

The towers of the possession tend to be square, rectangular or circular. They can overcome in one or two heights to the rest of the ensemble, and are built in stone and very unified in the total constructed area. Currently many of them have become part of the inhabited areas (Vibot, 2007).

Actually, this castellated image was the sign of prestige of the new settlers. In fact, it was common in many cases that the battlements that crowned the old and new buildings were nothing more than a mere ornament (Hernandez, 2014).

The initial mud walls and the paralleling of masonry of horizontal courses were gradually replaced by irregular masonry.

In the initial stages, the cover used to be flat, especially in those houses where there was a difficulty in placing tiles in an orderly manner. Over time almost all covers were modified to one- or two-sided roofs.

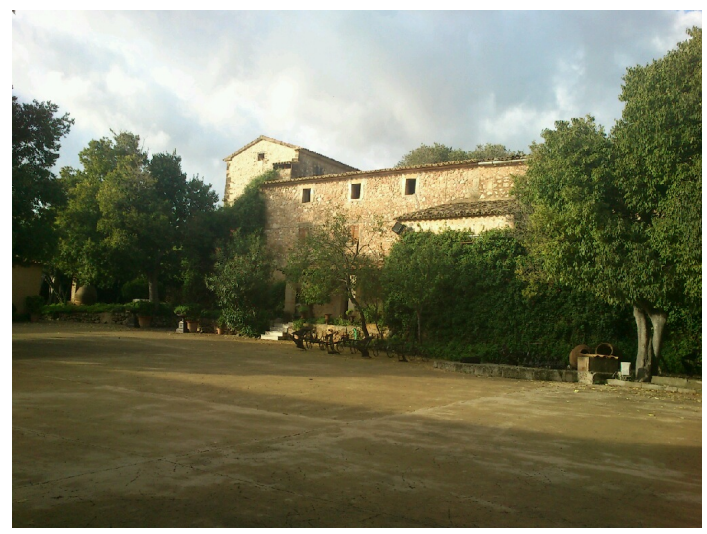

Possessió Son Tèrmens. Mallorca. Photograph: Joan Curós 


\section{The Cortijo}

The farmhouses are big farms and stockbreeders of hundreds of hectaresin Andalucía.

Their unlike location has driven to the existence of its variety. They can differ for being grain-producing or cattle-producing and simultaneously existing subtypes inside every type.

They are closed structures concerning a big courtyard, configured by the proper housing for the owner, buildings for storage like granaries or siloes, blocks for the animals, hayricks, etc. They project in its surroundings an open space with their corresponding accesses and cultivation.

It is common to find the farmhouses in high places, in the highest points of the hillocks to be able to dominate a big part of its grounds, and where there is more fresh breeze in summer evenings and produces a better stay; simultaneously this allowed to fan the grain pile. Nevertheless, many of them also appear in flatter areas. Another important aspect for its emplacement was the water supply.

There is noorientation that could be considered too disruptive, which gave some freedom in its establishment, but many of the cortijos stood facing east or south where the main facades of the houses stood, although there are several ones with opposite orientation. They look for the maximum of sunshine and light.

It always dominates in the cortijos a strong sense of horizontality: they are buildings of plain. Only occasionally are there a few block towers over others, increasing their relevance in the set. Usually it is the dwelling, but this does not distort the idea of horizontality (Florido, 1989).

The farmhouse is a dynamic, alive work, that has not been done with a preset plan but has been growing in different directions and organically as the needs were demanding and which has resulted in the configuration of the active set found today.

They are austere sets mainly with flat and smooth surfaces where elements like arches, balconies are rare. Also decorative simplicity is the norm and little more than a specific and very localized detail (a plaque, a tile with a picture, or the name of the farm) (Florido, 1989).

There are numerous windows, essential in a climate of high temperatures where the defence against heat is much more important than against the cold. This aspect entails that there is cross ventilation. In the outbuildings where ventilation is less important, the window size is smaller.

The portal of entrance to the courtyard is whether unbuilt or accessed through a dependency. On larger area farms there are several courtyards that have been formed through the evolution of the farm (Olmedo, 2010).

The kitchen is the main place in all the villages, located in an easily accessible place in the set, as the front body. It is the place where life is made, where people eat, cook and stay. 
The forges and ironworks were common units in cortijos since they allowed to carry out an essential work for agriculture like the repair and forging of the tillage implements. Some of them contained also the processing area of oil and wine.

Talking about constructive systems, in reference to walls, where stone is scare, those have been performed for centuries in the sedimentary areas by kneading and rolling the ground with some lime to give them major consistency. To construct them, two vertical and parallel wooden planks where placed which, mostly in the load-bearing walls, had a considerable thickness (often even more than $50 \mathrm{~cm}$ ). It was frequent as well that the walls were reinforced, whenever it was considered to be necessary but much especially in the granaries, whose walls had to support very high pressures.

The plaster of the walls was performed with plaster although nowadays the mortar is more frequently used. All the walls were impregnated with lime with a dazzling whiteness, only sometimes with a notice of yellowish ochre colour in the fronts or estates to give a decorative note. The white colour is due to the strong summer heat. The hollows of the facades are flat, slightly numerous, of limited size and have an irregular disposition provoked more by the needs that are generated from the interior of the building ventilation and lighting. There is a presence of arbours and verandas as intermediate spaces to live and work: (Olmedo, 2010).

The granaries are usually accommodated in buildings of two floors or in the first floor in order to prevent the moisture. To support the load and span distances, arcades and vaults were constructed on props in the ground floor, with wooden trusses in the deck and with a wooden structure on the rest of the slabs. The ground floor used to house livestock/cattle.

In the decks, due to the wood scarcity in the area, the use of charred log was frequent in a lot of dependences. The roof mainly gabled, with ridgepoles parallel to the facades, resting on the pairs, which are beams arranged towards the top axis every meter or meter and a half. There are roofs of one and four tails as well. There are also flat decks, sometimes made of soil, of brick or of mixes, although over time sloping decks were adopted. Every year the hut in the summer was tinked, assuming the roof had been very spoiled with the winter rains (Florido, 1989).

Even when risk is higher in fires rather than in rains, these were very frequent. Also strong winds were dangerous, as they completely dismantled the constructions.

From 1940 onwards, the replacing of the covers of half-burned logs began to take place and pine or chestnut wood appeared instead, sometimes also from eucalyptus or poplar and, less often, from olive tree or oak. It is coated then with Arabic tiles.

Courtyards used to be paved with pebbles. 


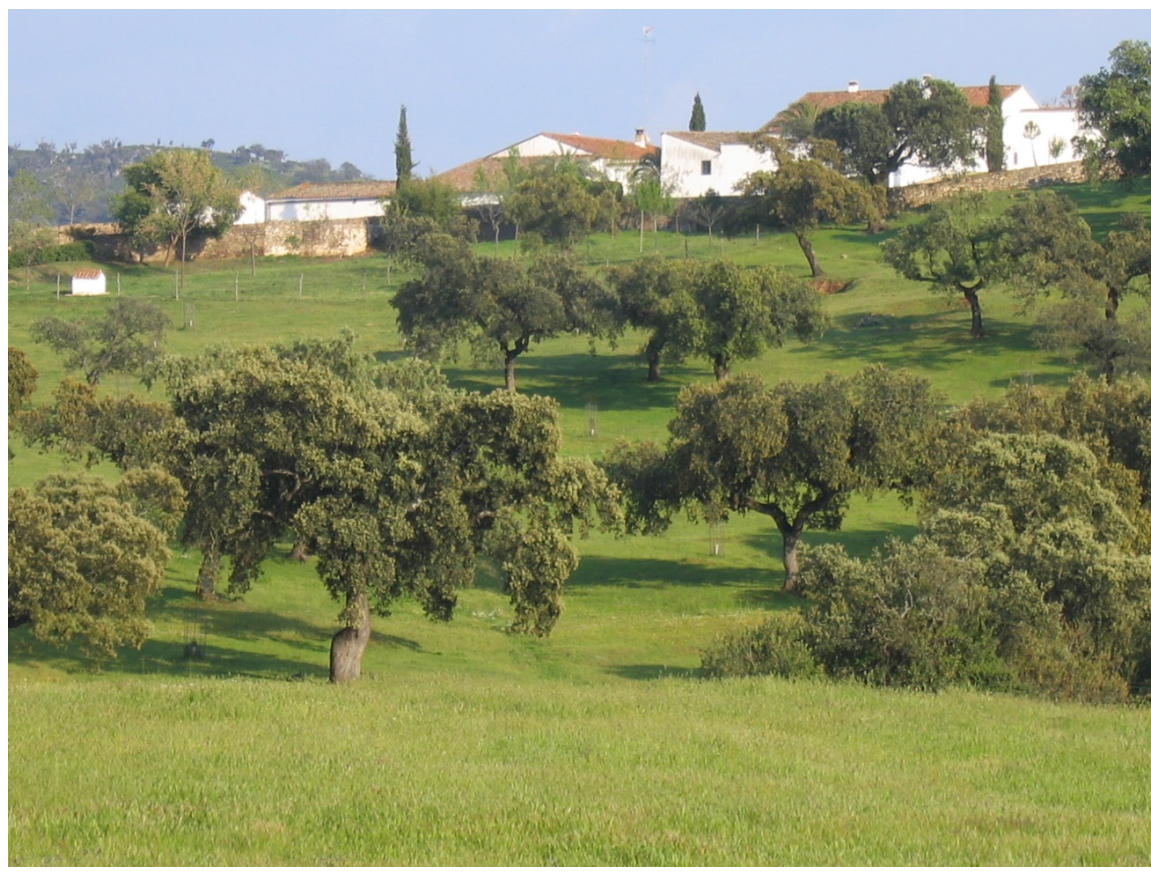

Cortijo Nava. Huelva. Photograph: Joan Curós

\subsection{Data Obtained}

There is no census or inventory of rural buildings in Spain and therefore information extraction is different in each community.

\subsubsection{Galicia}

The most comprehensive document and where the maximum number of buildings is inventoried are the two publications issued by the Association of Architects of Galicia and the Galician government entitled Pazos de Galicia. Análisis documentaly Pazos de Galicia. Catalog: files. There is an inventory of a totalof 645 pazos of which 209 belong to the Coruña, 149 to Lugo 170 to Pontevedra and 117 to Ourense.

According to the Galician regional government there are 120,000 agriculture farms but this does not mean that each one contains a pazo and the same occurs for the 140,000 remaining livestock farms.

According to data provided by the Department of Tourism of the Galician Government there are 86 pazos engaged in rural tourism oragrotourism, 15 of which are locatedin La Coruña, 19 in Lugo, 27 in Orense and 25 in Pontevedra.

\subsubsection{Basque Country}

There is an approximate census provided by the Statistical Department of the Basque Country. According to it, there are 5,400 caseríos, 742 of them are dedicated to rural tourism and agrotourism; 371 of them are in the Basque Country, 86 in Álava, 117 in Bizkaia and 168 in Gipuzkoa.

\subsubsection{Catalonia}

There is a detailed account for municipalities called "Catálogos de Masías", thought it is currently under development and it is performed in a $30 \%$ of the 
total.

In the doctoral thesis of Joan Curós a selection of 1283 equivalent masieswas made, approximately between $4 \%$ and $5 \%$ of which is about 30,000 masies.

According to 2014 data provided by the Department of Territory and Sustainability of the Generalitat de Catalunya, 2311 are devoted to rural tourism oragrotourism, 600 in the province of Barcelona, 784 in Gerona, 329 in Tarragona and 598 in Lérida.

The number of farms according to the Statistical Institute of Catalonia (Idescat) is 1646 .

\subsubsection{Valencia}

According to the website of the Valencian Government there are 27 huts catalogued, of which 19 of them are dwellings, and of these eight are inhabited, 3 are to reform, 2 act as workshop house, 2 are in ruin and 1 is a restaurant.

\subsubsection{Mallorca}

In the island of Mallorca there is no census of possessions either and we have to refer to the publications on the subject.

There is a publication entitled Les Balears written by Archduke Lluís Salvador, which referred to several possessions, another publication entitled Possessions de Mallorca, by Miquel Segura, which contains a substantial record, its four volumes include 120 registered possessions. With a smaller record there is the publication Les possessions de Mallorca, by Tomàs Vibot, containing a total of 45 possessions in two volumes.

From the Department of Tourism of the Majorcan Government there is a census of 231 possessions engaged in rural tourism.

\subsubsection{Andalucia}

In this community a census of cortijos is being prepared at the moment. According to the Andalusian Autonomous Govermnent, it will be finished in a few months.

So far there are few publications with high rigour on the Andalusian rural heritage published by the Autonomous Government itself. There is a publication for each province except for Huelva and Jaen, which are under development.

The publications have the title Cortijos, haciendas y lagares and in each one there is a list of inventoried buildings which is the most comprehensive documentation existing so far.

In Almería there are 423 inventoried cortijos, 105 of which appear studied in the publication and from this sample it can be assessed that $42 \%$ have no use, $16 \%$ have agricultural and livestock purposes and $30 \%$ have a residential use.

According to the Registry of Tourism of the Junta de Andalucía in 2014 there were 49 cortijos dedicated to rural tourism.

In the province of Cádiz there are 857 inventoried cortijos and 338 are studied in the publication, $86 \%$ of which are engaged in farming and ranching, $4 \%$ inresidential and hotel use and $9 \%$ have no use. 
24 of them are listed in the tourist registration of the Autonomous Government as they are engaged in rural tourism.

In Córdoba there are 1988 registered cortijos of which 799 are studied in the two volumes containing this collection. Of these, $61 \%$ are devoted to farming, $15 \%$ to residual agricultural use and $9 \%$ to the use of accommodation. And according to the Andalusian Goverment there are 27 registered ones intended for use in rural tourism.

In the province of Granada 2685 cortijos are registered and 229 of these are analyzed in that publication. 48 cortijos are inscribed in Tourism and are dedicated to rural tourism.

In Huelva and Jaén there are no registers of cortijos. Regarding rural tourism, though, there are 5 of them in Huelva and 24 in Jaén.

In Málaga province there are 1264 cortijos registered and 136 of them are studied in the publication of the Government of Andalusia. From this sample, $71.1 \%$ are devoted to farming and ranching, $12.59 \%$ to residential, hotel, museum, and social headquarters use and $16.30 \%$ lack of use.

In the Government's record of tourism there are 60 cortijos engaged in rural tourism.

Finally in Seville there are 2092 registered cortijos and 351 of them are studied in the publication on Cortijos, Haciendas y Lagares de Sevilla. 56\% of them are engaged in farming and ranching, $12 \%$ are devoted to non-farming activities, and activities related to hotel industry (accommodation, catering, events....) and the exclusive residential dedication, and $11 \%$ of them have no use.

According to the Andalusian Ministry of Tourism and Trade, there were in 2014a total of 13 cortijos dedicated to rural tourism.

\section{Results}

Many scientists are finding it difficult to come to grips with the new model of rural development that emerges slowly but persistently in both policy and practice. Nevertheless, we believe a paradigm shift is also taking place at the level of associated theory. The modernization paradigm that once dominated policy, practice and theory is being replaced by a new rural development paradigm (Van der Ploeg, Renting, Brunori, Knickel, Mannion, Marsden, de Roest, Sevilla-Guzmán, \& Ventura, 2000).

Agriculture is one of the most potent and enduring emblems of rurality. For centuries, agriculture was in most rural regions not only the overwhelmingly dominant source of employment, but also the driving force of the rural economy and a pervasive influence in the organization of rural society and culture.

In Spain, more than eight out of ten rural people were dependent on agriculture in 1970; by 2000 it was less than one in three. There are, of course, individual villages and towns in which agriculture is still the major employer, but these are increasingly confined to the more remote rural regions and even within such places farming tends to be significant rather than dominant in the local labour market. 
Many processes of rural restructuring involve a notion of modernization. Changes to farming practices, for example, were advanced under the banner of "agricultural modernization", which meant mechanization, specialization, larger farm units and the use of agri-chemicals and other technologies to maximize production (Woods, 2005).

The hectares of land retired under the European Union's set-aside scheme were 103.2 in 1988-92 875 in 1993-94 and 1610.6 in 2001-02, according to Ilbery and Bowler, 1998, European Union DGVI.

To assess the industrialization of agriculture, "industrialization" must be defined. The observed changes include increased labour productivity, purchased farm inputs and machines, crop specialization, land reorganization, huge irrigation works, international markets, complex output processing, and the appearance of large corporations.

Land and machinery investments are large-scale investments which must be amortized over long periods, making it difficult for farmers to respond to "market signals". This intensifies cycles of under- and over-production of particular commodities, which strongly affect profits and greatly increase investment risk.

Marx anticipated that these distinctions between agriculture and manufacture might disappear: they were moments in a historical process of uneven development of two sectors of necessary productive activity, under capitalism (FitzSimmons, 1986).

This state of affairs is increasingly unacceptable. Concentration in agricultural production, the overproduction of goods, the widening intervention of the state in agriculture, and the penetration of industrial and finance capitals into agriculture and the technological treadmill these create for producers, demand the further development of a political economy approach which relates specifically to capitalist agriculture (Marsden, Munton, Whatmore, \& Little, 1986).

The regional disparities increased and tensions grew between farming on the one hand and landscape, nature, environment and product quality on the other (Roep, 2000).

Current modern housing systems are poorly designed when considering the behavioural and adaptive needs of animals. Systems are often simple in design and boring in its in appropriate use of materials (Pond, Bazer, \& Rollin, 2012).

Within the framework of rural development new forms and mechanisms for co-ordination and conflict management must be developed. This will become increasingly important as new forms of farm-based rural development activities emerge and different actors compete for access to opportunities and resources in new arenas such as rural tourism and nature and landscape conservation.

Pluriactivity can no longer be seen as heralding the demise of the farm, rather it has become one of the new pillars supporting European farming.

In recent years a more holistic view of multifunctionality has emerged, which that places more emphasis on the interlink ages of the concept with rural development, culture, the consumption countryside, societal needs, agency-led patterns and processes of agricultural and rural change, as well as environmental issues (Wilson, 2007). 
Certainly there are new societal demands for tourist experiences, quality products, and an environment with high natural value; the same demands represent new opportunities for farmers and other rural entrepreneurs. In many rural areas, there is a realignment of sector activities to strengthen the interrelatedness of activities. Agriculture can play a crucial role here, since the diversity of natural habitats and the scenic beauty of landscapes are closely related to the type and intensity of land use and provide a new resource base for the development of rural or Green tourism (Van der Ploeg, Renting, Brunori, Knickel, Mannion, Marsden, de Roest, Sevilla-Guzmán, \& Ventura, 2000).

Selecting a specific set of non-traditional farm-based activities in tourism, the method she this set develops indicates how precise spatial targeting could assist the optimum location of activities from the point of view of archieving rural policy targets for economic activity and population levels (Midmore \& Harrison, 1996).

Rural tourism is the one with most different forms depending on the territory. These include, for example, rural guesthouses of Valencia, the Balearic rural tourism farms and the País Vasco, the masia of Catalonia, the rural estates in Galicia and the Balearic Islands, and the manors and the pazos and villages of rural tourism in Galicia (Gil \& Ribeiro, 2015).

Other policy issues relate to the environment of rural areas. To some extent these are linked to the grand question of trade liberalisation and how it affects rural economies: at least opportunistically, because they open up "green boxes". Extension of multi-sector economic modelling to include natural environmental systems has so far been explored inadequately. Equally, though, much of the current discussion of policy development is dominated by the difficulty of applying the principle of sustainability. By refocusing its capability for structural analysis, the multi-sector modelling approach has much to offer here (Midmore \& Harrison, 1996).

Policy developments concerned with the environment and nature suggest an extension of the agricultural work on "nature-society relations" (Morris \& Evans, 2004).

One such theme, which has only recently attracted the sustained gaze of rural researchers is the commodification of rural areas, where rural environments are being exploited to match the demands of contemporary consumption.

A "new age" of ecology, however, has begun in a slow, fledgling and uneven way, and it demands significant comparative analysis. The concepts are by no means exclusive to the sub-discipline. However, they represent central critical connections or bridgeheads through which such disciplines and theories could be progressed (Marsden, 2004).

Commodification includes profiting from new forms of organizing recreation, leisure and tourism, which can be sold in a more privatized "pay-as-you enter" type of rural environment. It includes the development of particular styles of living through special riches in the rural housing market (such as service class development). It even includes a reorganization of labour requirements, both to 
service these other commodities, and indeed maintain the backdrop of a manicured rural landscape which is, the necessary context for those commodities (see Cloke \& Goodwin, 1992).

\section{Conclusion}

Rural areas and the agricultural sector are currently subject to a number of changes (Van Huglenbroeck \& Durand, 2003).

Capitalist modes of production have dominated the exploitation of rural resources in the modern era, but the conditions of operation of agrarian and resource capitalism have varied both temporally and geographically, framed by different political-economic regimes (Woods, 2010).

All this does not prevent the new rurality to be set in every time more diversified activities, and increasingly dependent on endogenous characteristics of each area, whether called rural tourism, natural resources, or processing of raw materials, not to mention that the attraction certain rural areas are beginning to exercise towards the implementation of certain industries linked to leisure.

Agriculture is no longer the main source of income of rural households and this role is taken by other sources such as services, rural industry or even construction. All these sectors are growing at the expense of agriculture (Garcia, 1998).

In fact, in some rural households there are a growing number of rents which are obtained from non-agricultural activities. At the same time, not all incomes generated by agriculture are perceived by agricultural households (García, 2011).

In data obtained for the accomplishment of this research provided by the respective regional governments of Spain, it is worth noting that there is no comprehensive record of them, notwithstanding there is some key data in which we can detect that the rural architecture dedicated to tourism is more relevant in the north of Spain than in the rest of the country. This leads at the same time to greater economic investment in rural heritage of the north to the adaptation and conversion of new uses in these buildings.

The number of active arable and livestock farming is by far much higher than in farms dedicated to tourism or reconversion for a use change. There is currently no record to deduce whether these exploitations have been industrialised since the existence of folk architecture or if many of them are newly created. Still both require a much higher economic investment than the one needed for the adaption to new uses of the building.

The main conclusion is that the agricultural innovation systems' perspective provides a comprehensive view on actors and factors that co-determinate innovation, and in this sense allows understanding the complexity of agricultural innovation (Darnhofer, Gibbon, \& Dedieu, 2012).

\section{Acknowledgements}

I would like to thank all the regional governments of Spain, the representative architecture of which is targeted in this investigation and the Central Govern- 
ment itself and public and private institutions for facilitating and collaborating on data reported so far on this issue.

\section{References}

Ainz, M. J. (2001). El caserío vasco en el país de las industrias. Madrid: Ministerio de Agricultura, Pesca y alimentación.

Baeschlin, A. (1968). La arquitectura del Caserío Vasco. Bilbao: Biblioteca Vascongada Villar.

Cloke, P., \& Goodwin, M. (1992). Conceptualizing Countryside Change. From PostFordism to Rural Structured Coherence. Transactions of the Institute of British Geographers, 17, 321-336. https://doi.org/10.2307/622883

Curós, J. (1995). Arquitectura rural de laGarrotxa. Estudi estructural. Girona: COAiATG, Diputació de Girona i UdG.

Curós, J. (1999). Arquitectura rural de laGarrotxa. Estudi estructural-Estudio estructural (2 ed.). Girona: COAC.

Curós, J. (2004). Arquitectura rural de Catalunya. Metodologia d'anàlisi i d'intervenció. Barcelona: UPC.

Curós, J. (2006). La masia: Un referent arquitectònic. Barcanova, Barcelona: Masies que cal conèixer.

Darnhofer, I., Gibbon, D., \& Dedieu, B. (2012). Farming Systems Research into the 21st Century. The New Dinamic. New York, NY: Springer, Cop.

https://doi.org/10.1007/978-94-007-4503-2

Del Rey, M. (2010). Arquitectura rural valenciana. Cabrera de Mar: Galerada.

Duch, G. (2010). Lo que hay que tragar. Minienciclopedia de política y alimentación. Barcelona: Los libros del lince.

Etxezarreta, M. (1977). El caserío vasco. Bilbao: Undación C. de Iturriaga y M. de Dañobeitia.

Etxezarreta, M. (1979). La Evolución del campesinado. La agricultura en el desarrollo capitalista. Madrid: Inisterio de Agricultura, Pesca y Alimentación.

FitzSimmons, M. (1986). The New Industrial Agriculture: The Regional Integration of Specialty Crop Production. Economic Greography, 62, 334-353. https://doi.org/10.2307/143829

Florido, G. (1989). El cortijo andaluz. Sevilla: Junta de Andalucía.

García, B. (1998). La Sociedad Rural ante el siglo XXI. Madrid: Ministerio de Agricultura, Pesca y Alimentación.

García, B. (2011). Ruralidad emergente. Posibilidades y retos. Madrid: Ministerio de Medio Ambiente, Medio Rural y Marino.

García, J. (1975). Organización del espacio y economía rural en la España Atlántica. Madrid: Siglo XXI editores.

García, N., \& Oliver, S. (1986). Cases de possessió. Palma: COAIB.

Garrabou, R. (2010). Sombras del progreso. Las huellas de la historia agraria. Barcelona: Editorial Crítica.

Gil, S., \& Ribeiro, M. (2015). Los establecimientos de alojamiento turístico en España y Portugal. Revista de la Asociación Española de Contabilidad y Administración de Empresas, $A E C A, 109,28-31$.

Giménez, C., \& Sánchez, L. (1994). Unidad y diversidad en la colonización agraria. Perspectiva comparada del desarrollo de las zonas regables. Madrid: Ministerio de Agricultura, Pesca y Alimentación, Ministerio para las Administraciones Públicas y Ministerio 
de Medio Ambiente.

Gosálvez, V. (1998). La barraca valenciana. Col-legi Oficial d’Arquitectes de València, Valencia

Hernández, C. (2014). Orígenes medievales de las casas de Andratx (Mallorca): Aportación al conocimiento de la formación de los tipos de la arquitectura tradicional local. Tesis Doctoral, Madrid: Universidad Complutense de Madrid.

Marsden, T., Munton, R., Whatmore, S., \& Little, J. (1986). Towards a Political Economy of Capitalist Agriculture. A British Perspective. International Journal of Urban and Regional Research, 10, 498-521. https://doi.org/10.1111/j.1468-2427.1986.tb00026.x

Marsden, T. (2004). The Quest for Ecological Modernisation: Re-Spacing Rural Development and Agri-Food Studies. Sociologia Ruralis, 44, 129-146. https://doi.org/10.1111/j.1467-9523.2004.00267.x

Midmore, P., \& Harrison, L. (1996). Rural economic modelling. An input-output approach. Wallingford: CAB International, Cop.

Monclús, F. J., \& Oyón, J. L. (1988). Políticas y Técnicas en la Ordenación del Espacio Rural. Madrid: Ministerio de Agricultura, Pesca y Alimentación, Ministerio para las Administraciones Públicas y Ministerio de Obras Públicas y Urbanismo.

Morris, C., \& Evans, N. (2004). Agricultural Turns, Geographical Turns. Retrospect and prospect. Journal of Rural Studies, 20, 95-111. https://doi.org/10.1016/S0743-0167(03)00041-X

Naredo, J. M. (1996). La Evolución de la Agricultura en España (1940-1990). Granada: Universidad de Granada.

Olmedo, F. (2010). Cortijos, haciendas y lagares en Andalucía. Sevilla: Junta de Andalucía.

Pérez, P. (2010). El Hórreo Gallego y su simbolismo en los Pazos de Ulloa. Garoza, NO. 10, 195-202.

Pond, W. G., Bazer, F. W., \& Rollin B. E. (2012). Animal Welfare in Animal Agriculture: Husbandry, Stewardship and Sustainability in Animal Production. Boca Raton, FL: CRC Press, Cop.

Roep, D. (2000). Vernieuwend werken, sporen van vermogen en onvermogen. Een socio-materiele studie over vernieuwing in de landbouw uitgewerkt voor de westelijke veenweidegebieden. $\mathrm{PhD}$ Thesis, Wageningen University, Wageningen.

Sanchís, M. (1999). Les barraques valencianes. Valencia: InstitucióAlfons el Magnànim.

Valero, G. (2014). Les possessions de la serra de Tramuntana. Història i patrimoni. Palma de Mallorca: IEC.

Van der Ploeg, J. D., Renting, H., Brunori, G., Knickel, K., Mannion, J., Marsden, T., de Roest, K., Sevilla-Guzmán, E., \& Ventura, F. (2000). Rural Development from Practices and Policies towards Theory. Sociologia Ruralis, 40, 481-496. https://doi.org/10.1111/1467-9523.00156

Van Huglenbroeck, G., \& Durand, G. (2003). Multifunctional Agriculture: A New Paradigm for European Agriculture and Rural Development. Aldershot: Ashgate, Cop.

Vibot, T. (2007). Possessions de Mallorca. Mallorca: El Gall Editor.

Villanueva, A., \& Leal, J. (1991). La planificación del regadío y los pueblos de colonización Vol. 3. Madrid: MAPA, MAP, MOPU.

Wilson, G. (2007). Multifunctional Agriculture: A Transition Theory Perspective. Wallingford: CABI, Cop.

Woods, M. (2005). Rural Geography. Processes, Responses and Experiences in Rural Restructuring. London: SAGE.

Woods, M. (2010). Rural. New York and London: Routledge. 
Submit or recommend next manuscript to SCIRP and we will provide best service for you:

Accepting pre-submission inquiries through Email, Facebook, LinkedIn, Twitter, etc. A wide selection of journals (inclusive of 9 subjects, more than 200 journals)

Providing 24-hour high-quality service

User-friendly online submission system

Fair and swift peer-review system

Efficient typesetting and proofreading procedure

Display of the result of downloads and visits, as well as the number of cited articles Maximum dissemination of your research work

Submit your manuscript at: http://papersubmission.scirp.org/

Or contact adr@scirp.org 